totality will continue about $3 \mathrm{~m}$. $38 \mathrm{~s}$., with the sun at an altitude of $50^{\circ}$ and near the meridian.

(6) 1889 , DECEMBER 22.- The greater duration of totality in this eclipse falls upon the Eastern Atlantic, but where the central line meets the African coast in Angola (about $10^{\circ} 6^{\prime} \mathrm{S}$.) it continues $3 \mathrm{~m}$. 35s., with the sun at an altitude of $56^{\circ}$. At Bridgetown, Barbados, totality commences about $6 \mathrm{~h} .47 \mathrm{~m}$. A.M., with the surs at an elevation of $6^{\circ}$, and continues Im. $48 \mathrm{~s}$.

(7) I 892, APRIL 26.-Almost entirely an ocean track on the South Pacific, commencing indeed in the Antarctic Ocean at a latitude of upwards of $75^{\circ}$ : an impracticable eclipse, though the duration of totality attains a maximum of more than four minutes.

(8) 1893, APRIL I6.-Probably, all classes of observation considered, this will be the most favourable eclipse occurring before the end of the century. On the west coast of South America, rather less than a degree north of Coquimbo, where the sun will have attained an altitude of $24^{\circ}$, totality will continue nearly three minutes, commencing about $8 \mathrm{~h}, 14 \mathrm{~m}$. a.m.: hence the central line traverses Brazil, passing off the South American continent near Ciara, and here the sun, at an altitude of $77^{\circ}$, and near the meridian, will be totally eclipsed $4 \mathrm{~m}$. $44 \mathrm{~s}$., or within a second or two of the longest interval possible on this occasion. Perhaps the central eclipse may pass about $\mathrm{IO}^{\prime}$ north of Ciara. After traversing the Atlantic it enters Africa close to Bathurst, at the mouth of the Gambia, where the total phase still continues about four minutes, thence through Central Africa to a point from $4^{\circ}$ to $5^{\circ}$ west of Khartoum, where it leaves the earth. From these circumstances an extended course of observations may be expected.

(9) 1894, SEPTEMBER 28.-On this occasion we have either a sea-track or a passage over inaccessible regions, except that the eclipse may ultimately be found to be total in the Seychelles; the tabular position of the moon, upon which our calculations referring to this phenomenon are founded, perhaps admitting of alteration to the amount required. The central line commences in the middle of Africa just north of the equator, leaving that continent near the Juba River, the mouth of which is almost upon the equator. "In the longitude of Mahe in the Seychelles it appears to pass about $38^{\prime}$ to the south. The maximum duration of totality occurs in about $86^{\circ} \mathrm{E}$. and $34^{\circ} \mathrm{S}$., and is close upon two minutes. From this point the course of the central line is in the direction of Macquarie Island, near to which it passes off the earth, without, so far as a preliminary computation enables us to say, certainly encountering land after leaving the African continent.

(10) 1896, AUGUST 9.--Stations will doubtless be found for the observation of this eclipse, as although in the first half of its course, at least, the track lies at considerable northern latitudes, the season of the year is favourable. The central line enters Norway, near Tana in Finmark, and in $28^{\circ} 46^{\prime} \mathrm{E}$. and $70^{\circ} 31^{\prime} \mathrm{N}$. the duration of totality is $1 \mathrm{~m} .43 \mathrm{~s}$. with the sun at an altitude of $15^{\circ}$. After rising to a still higher latitude the central eclipse begins to descend, until we find it occurs with the sun on the meridian in about $112^{\circ} 21^{\prime}$ E. and $65^{\circ} 38^{\prime} \mathrm{N}$., and the latitude continues to diminish until the total phase leaves the earth. In $136^{\circ} 21^{\prime} \mathrm{E}$. and $51^{\circ} 5^{\prime} \mathrm{N}$, near the Amoor River totality continues $2 \mathrm{~m}$. 38s. with the sun at an altitude of $46^{\circ}$. The total eclipse may be observed also in the northern parts of Yesso, Japan, but does not afterwards meet land. [This will be a recurrence of the eclipse of 1806 , June 16 , observed by Bowditch in America, of that of 1842 , July 8 , well observed in the South of France and in Italy, and of the "Himalaya eclipse" of 1860 , July I8, when a numerous party was conveyed to the south-west of Europe in H.M.S. Himalaya, there meeting with observers from all parts of the Continent, and unitedly putting upon record important details of the phenomena observed. Its last recurrence was on July 29,1878 , when so good an account of it was given in the United States by American and European astionomers.]

(II) I898, JANUARY 22.-This eclipse may be well observed in Hindostan, where the central line enters the peninsula in about $73^{\circ} 25^{\prime} \mathrm{E}$. and $16^{\circ} 38^{\prime} \mathrm{N}$.; totality will commence at oh. $45 \mathrm{~m}$., and continue about $2 \mathrm{~m}$. $6 \mathrm{~s}$. It commences in Senegambia, and leaves the earth in East Mongolia. Although many observations may probably be made in India, it will be seen that the duration of the total phase is comparatively short.

(I2) I $900, \mathrm{MAY} 28$. - The central line entering upon the earth in the Pacific in $18^{\circ} \mathrm{N}$. traverses the south-east portion of the United States, from Louisiana (not far from New Orleans) to Norfolk, on the Atlantic coast, and at the point where it leaves the American continent totality commences about $8 \mathrm{~h}$. $47 \mathrm{~m}$. a.m., and continues Im. 40 . with the sun at an altitude of $47^{\circ}$. Crossing the Atlantic, upon which the greatest duration of totality falls, it enters Portugal near Ovan in about $40^{\circ} 49^{\prime} \mathrm{N}$, and here the total phase continues Im. 3os., with the sun at an elevation of $42^{\circ}$. The eclipse may be well observed in Portugal and Spain; at Alicante totality lasts Im. I8s. This eclipse will be a recurrence of that of May, 1882 , and the available durations of totality, it will be seen, are about the same on both occasions. In Hallaschka's Elementa Eclipsium, by an oversight, this eclipse is represented as broadly annular; the geocentric excess of the moon's semi-diameter over that of the sun will be, however, about $9^{\prime \prime}$

The following table exhibits the approximate positions of beginning and ending of total phase, and of the central eclipse at apparent noon, for the twelve eclipses included in the above remarks :-

$1882 \ldots 3^{\circ} 1 \mathrm{~W} .10^{\circ} 7 \mathrm{~N}$. 63.8 E. $38^{\circ} \cdot 8 \mathrm{~N}$. $138^{\circ} \cdot 9$ E. $25^{\circ} 5 \mathrm{~N}$ $34^{\circ} \mathrm{S}$ S. $147^{\circ} 2 \mathrm{~W} .9^{\circ} 2 \mathrm{~S} . \quad 86^{\circ} 9 \mathrm{~W}, 3^{\circ} \cdot 6 \mathrm{~S}$

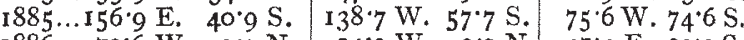
$1886 \ldots 79^{\circ} 6 \mathrm{~W} .99^{\circ} \mathrm{N}$. I $4^{\circ} 2 \mathrm{~W} .3^{\circ} \mathrm{O}$ N. $47^{\circ} 3 \mathrm{E} .22^{\circ} \mathrm{OS}$ $1887 \ldots$ II. 7 E. $51^{\circ} 6 \mathrm{~N}$. 102.3 E. $53.8 \mathrm{~N}$. I $73.8 \mathrm{E} .24^{\circ} 5 \mathrm{~N}$ $1889 \ldots 78.9 \mathrm{~W}$. $15.4 \mathrm{~N}$. $6.5 \mathrm{~W}$. II. S S. $60^{\circ} 9 \mathrm{E} .6 .9 \mathrm{~N}$ $1892 \ldots 144^{\circ} \mathrm{I}$ W. $76 \cdot 1 \mathrm{~S} . \quad 138 \cdot 7 \mathrm{~W}$ W. $67.3 \mathrm{~S} . \quad 81 \cdot 7 \mathrm{~W} .38 \cdot 4 \mathrm{~S}$ $1893 \ldots 95^{\circ} 7$ W. $36^{\circ} 3 \mathrm{~S}$. $36^{\circ} 6 \mathrm{~W}$. I $\circ \mathrm{S} .28 \cdot 6 \mathrm{E} .16^{\circ} 4 \mathrm{~N}$ $1894 \ldots 26.9 \mathrm{E} . \quad \mathrm{I} \cdot 7 \mathrm{~N} . \quad 86.3 \mathrm{E} .34^{\circ} 3 \mathrm{~S} .163^{\circ} \circ \mathrm{E} .56^{\circ} 4 \mathrm{~S}$, $1896 \ldots$ I. $10 \mathrm{~W} .63 .5 \mathrm{~N}$. 112.4 E. $65.6 \mathrm{~N}$. I79.1 W. $18.6 . \mathrm{N}$ $1898 \ldots$ 10.0 E. II ${ }^{\circ} \mathrm{N} .68 .8 \mathrm{E}$. $12.9 \mathrm{~N}$. II $9.3 \mathrm{E} .45^{\circ} 9 \mathrm{~N}$ $1900 \ldots 116.6$ W. $18.0 \mathrm{~N} .44 .8 \mathrm{~W} .45^{\circ} \mathrm{N} .3^{\circ} 8 \mathrm{E} .25^{\circ} 4 \mathrm{~N}$.

\section{A CHAPTER IN THE HISTORY OF THE CONIFERAE}

\section{THE CUPRESSINEA}

THESE are classed as the first tribe of the Coniferæ in Hooker's "Genera Plantarum," wherein seven genera are recognised. The Cupressineæ are large trees or shrubs, very resinous, with small scale-like leaves. The cones are small and globular, and composed of six, eight, or rarely ten peltate and persistent scales, except in the juniper, in which they coalesce into a fleshy galbulus or berry. The seeds are small, compressed, frequently triangulated, and, except in Juniperus and the Biota section of Thuja, provided with small membranaceous wings at the angles. The order comprises many of the hardiest shrubs in existence.

Their origin can possibly be traced back to the Permian genus Ulmannia, and they seem to have become the preponderating tribe during the Jurassic and Wealden, to judge from the prevalence of wood known as Cupressinoxylon. The earlier forms, described as Widdringtonites, Echinostrobus, Thuyites, and Thuyopsis, though of great interest are still imperfectly known, even from the Cretaceous, but with the Tertiary period most of the

\footnotetext{
I Continued from vol, xxiii. p. $4^{\mathrm{r}} 4$.
} 
existing genera appear, apparently as completely differentiated from each other as at the present day.

A few of the Cupressineæ, as cypress and some of the junipers, inhabit swamps or places liable to inundation, while other species of the same genera seek out the loftiest mountains and excel almost all other shrubs in hardiness, the juniper and cypress being found in Central Asia at altitudes respectively of 15,000 and 16,000 feet.

Many of them seem able to adapt themselves to a great range of climate. Fitzroya, a stately cedar 100 feet in height on the western slope of the Patagonian mountains, dwindles to a small bush a few inches high on the confines of perpetual snow, and the Chilian Libocedrus, Ioo feet high on the Cordilleras, dwarfs to a small bush in Magellan. Of all the genera, however, Juniperus is the most hardy, extending itself as low scrub-bushes on most mountain chains to far beyond the limits of trees, and occupying to the south the barren rocks of Cape Horn ( $J$. uvifera), and to the north penetrating Labrador, Newfoundland, Hudson's Bay, and Greenland (/. Canadensis).

Although of relatively less bulk than the Sequoiz or the Pines, some species attain colossal dimensions, as the Oregon red cedar, Thuja gigantea. This tree, said by Gordon to be from 50 to 150 feet, and by Herschel 200 feet, high, seems actually to have reached an altitude of 325 feet, and a diameter of 22 feet, for a gigantic plank, exhibited by the State of Oregon at the Philadelphia Exhibition, was stated to have been cut at II 8 feet from the ground from a trunk of these dimensions. Libocedrus decurrens exceeds 200 feet, and in the Himalayas the gloomy Cupressus torrulosa has been met with 150 feet in height and 16 feet in girth at five feet from the ground.

The woods of many of the species are valuable-those of Frenela columnaris, Callitris quadrivalvis, and some species of juniper being esteemed by cabinet-makers for furniture and veneering. The mottled butt wood of the "Thuja" of Pliny, and the "citrus" of Horace commanded fabulous prices during the Roman Empire. Cicero is said to have paid a million sesterces ${ }^{1}$ (900ol.) for a table made from this wood, and of two tables belonging to King Juba, and sold by auction, one fetched $1,200,000$ sesterces, although the largest recorded diameter is only about $4 \frac{1}{2}$ feet. The wood is still turned into tazza in Paris, and examples of it are preserved in the Kew Museum. Some of the most valuable gums, balsams, and resins, and amber are obtained from the tribe.

The first, and palæontologically most important, genus is CALLITRIS. This is subdivided into four sections, by many authors recognised as distinct genera-(I) Pachylepis or Widdringtonia; (2) Tetraclinis or Callitris proper; (3) Hexaclinis or Frenela; and (4) Octoclinis. The first section is doubtfully recorded as Widdringtonites, from the Lias of Switzerland and Würtemberg and from the Wealden and Cretaceous of North Germany, and Kome in Greenland. Widdringtonia is definitely found at Aix and other Eocene localities of France by Saporta, in the Miocene of Oeningen, at Bilin, and questionably so in the absence of fruits in the Greenland Eacene. It is now confined to South Africa and Madagascar.

The second section, Callitris proper, is distinguished by its cone formed of four truncated valves in pairs, and is represented at present by a single species confined to Northern Africa. Its fruits however are not only met with at Sheppey, but at Aix, St. Zacharie, and Armissan in France, and at Häring in the Tyrol.

Between this and the next section of Callitris should be placed, if cupressineous at all, the extinct genus (?) Solenostrotus of Endlicher, founded on Bowerbank's figures of fruits with five valves each.

The third section, Frenela, has a cone of six scales in

$$
\text { I Hooker, "Tour in Marocco," p. } 389 .
$$

opposite pairs, and is now entirely confined to Australia and New Caledonia, nearly two dozen species being more or less known. One of the most distinctly Cupressineous fruits yet met with fossil corresponds exactly with the Port Jackson $C$. Endlicheri, but has eight scales, and therefore falls into the Octoclinis section, also Australian, but now limited to a single species.

We have thus the most absolute proof that different sections of CALLITRIS flourished in these latitudes during the Eocene period, and therefore that the Palæarctic, Ethiopian, and Australian botanical regions overlapped and intermingled to some extent at that time. They do not seem, however, to have been present much to the north of our own latitude.

The genus ACTINOSTROBUs does not appear to have been found fossil except by Ettingshausen at Sagor (1859), and even these two specimens seem very indistinct and much smaller than either existing species, and are ignored by Schimper in his list of species. The existing Patagonian FITZROYA has no known fossil representative.

The fourth genus, LIBOCEDRUS, is distinguished by its flattened oblong cone of four to six leathery and very unequal scales, and by its thick scale-like and peculiar foliage. It occasionally forms very large trees, and in distributed over all but the Oriental and Ethiopias regions, ${ }^{1}$ though the actual species have a limited range. The range of Libocedrus in the Tertiaries is singular. It appears from below the London clay at Bromley, then completely disappears in Europe until the Miocene, when it reappears at Bilin, Schossnitz, Radaboj, Armissan, Sinigaglia, from near Bonn, from Monod in Switzerland, and the amber-beds of Prussia. Another species, said to be allied to the Chilian tree, is found in the Eocene of Greenland. As most of the species of Libocedrus inhabit considerable altitudes, even reaching the snow level, and all of them are hardy in England, it is fair to infer that prior to the London clay the climate (and this is borne out by the rest of the flora) was much cooler than during subsequent Eocene times. That Libocedrus was really absent from temperate Europe during the latter part of the Eocene period is beyond all doubt, and that we actually experienced a change in climate such as had been inferred from the faunas of the Thanet sands and Woolwich and Reading beds is fully confirmed by the flora.

THUYA has small ovate or oblong cones of 6-Io valvate unequal scales, and foliage somewhat similar to Libocedrus, though less symmetric. There exist twelve to twenty-one species, divided into five sections, and some forming trees that are gigantic. The great majority are Japanese, but two species inhabit the Nearctic regions. The genus first appears in the Arctic Eocenes, descending into Europe during the Miocene, when it formed the vast amber-producing forests along the Baltic. The oldest beds to the south from which it is known, though it is rare there, are those of Armissan in France, and the late Miocenes of Marseilles and Tuscany. It is unknown from England, and the Chamecyparites of the older Eocenes of Europe are now transferred to Sequoia.

The sixth genus, the stately CUPRESSUS, is only known fossil from two German Miocene localities. The existing species are mostly found in mountainous regions.

The seventh genus, JUNIPERUS, is very extensive, and is present in every geographical region except the Australian, being also one of the three British indigenous Gymnosperms. It has been recorded fossil from Aix, Häring, and the amber-beds of Prussia, but the smallness of the fragments and the absence of any traces of berries renders its occurrence, especially in the former localities, somewhat doubtful.

The range of the fossil CUPRESSINEE, as ascertained throughout the Tertiaries, is thus seen to be perfectly

\footnotetext{
I As restricted by Wallace.
} 
natural ; the hardy genera are never associated with the more tropical Eocene floras, and the sub-tropical genera did not range farther north than the present temperate latitudes, nor extend into the later Miocenes. Hardy species occupied these latitudes in the old temperate Eocene times, retreated as the temperature increased, and re-descended from the north as it again decreased, reaching finally as far south as North Italy. The habits and even the species of the genera have not materially altered since the Tertiaries commenced, and they appear to furnish comparatively safe data for physiological inquiries. The most remarkable fact taught by them, a fact beyond all question, is that types now distinctive of widely separated botanical regions actually lived side by side together in Western Europe in the Eocene age.

As the true nature of the various Eocene and Miocene floras becomes unfolded, thanks principally to the able work of Saporta, the fluctuations in temperature that Europe and America have experienced will be measurable and their ebb and flow calculable, with some approximation to certainty. The sensational extremes implied by the over-positive determination of fragments that no human being could determine with certainty, will then, it is to be hoped, be once and for ever discredited.

\section{THE STORAGE OF ELECTRTC CURRENTS}

PRACTICAL electricians seem to have made up their minds that a system for the distribution of electricity for the purposes of electric lighting or of driving electric motors will be incomplete unless it comprises a means of storage of the currents to provide against the risk of any temporary derangement or inconstancy in the generating apparatus. An accumulator of currents would in fact render the same service in an electrical system as do gasometers in systems for distributing gas, or the hydraulic accumulators in a system of hydraulic machinery.

At the present time much attention is directed to such accumulators, or, as they have been hitherto called, secondary batteries.

The principle of the secondary battery dates back to the very early days of Voltaic electricity, when in r8or, one year after Volta's "pile" had made its appearance, Gautherot, a French savant, observed that wires of platinum or of silver which had served as electrodes for the decomposition of water containing a little salt or sal ammoniac acquired the property of giving a brief current after being detached from the pile. This phenomenon, familiar to every electrician under the name of "polarisation of the electrodes," was observed again by Ritter of Jena, in 1803 , with electrodes of gold wire; and the observation immediately led him to devise a battery from which these secondary currents could be readily obtained, and which constituted the first of all secondary batteries. He tried many different arrangements, using various metals-platinum, silver, iron, \&c., but with lead he obtained no result. He attributed this secondary action to a soaking or accumulating of the two opposite kinds of electricity into the surfaces of the plates or into the intervening liquid. The true explanation was given by Volta and Marianini, and later by Becquerel, when they showed that the action arose from the deposits of oxygen and hydrogen, or of acid and of base upon the two electrodes, whose surfaces thus became chemically changed and capable of acting towards one another like the zinc and copper plates of an ordinary battery. Grove, in 1843 , brought the matter to a decisive proof by constructing his curious gas battery, in which the positive and negative poles were both platinum plates, the one surrounded by oxygen gas, the other by hydrogen. Ritter's failure to obtain any effect from electrodes of lead arose from his employment of solutions of chlorides as the liquid, the chloride of lead which resulted on the passing of the current being a non-conductor, which at once stopped the current. M. Gaston Planté, who, in I859, took up the study of the subject, found, after experimenting with many metals, that electrodes of lead, when immersed in dilute sulphuric acid, gave rise to very marked polarisation-effects ; for after passing through lead electrodes the current from two Bunsen's cells, the

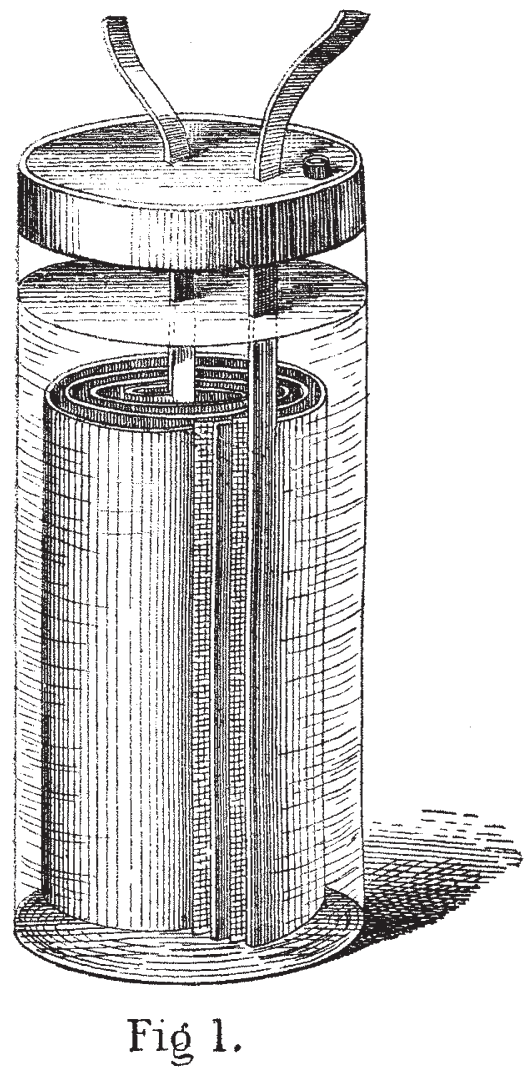

This figure represents two sheets of lead, separated by two sheets of canvas rolled up together and placed in a glass jar containing water, two strips of sheet-lead protruding through the closed top of the jar.

secondary currents were extremely strong and of considerable duration. He therefore constructed large secondary batteries, using for this purpose two sheets of lead immersed in dilute acid. In order to reduce the internal resistance by bringing the opposed surfaces as nearly as possible together the two sheets were of large size and

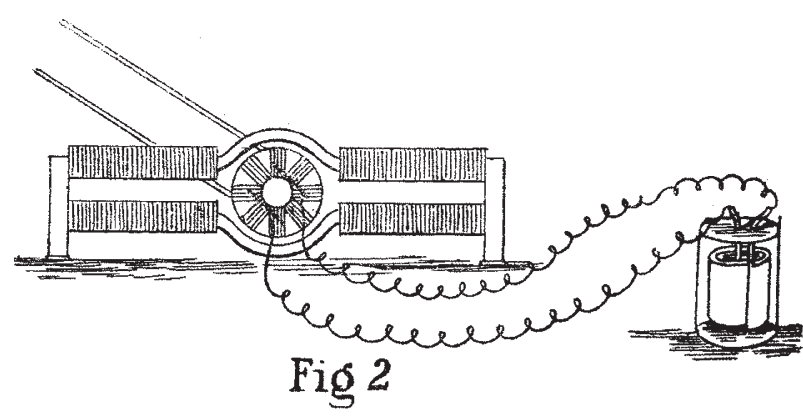

were rolled together in a spiral form, being kept from touching by the interposition of sheets of coarse canvas, or in later forms by means of bands of india-rubber. The general form of a single cell of Plantés secondary battery is shown in Fig. I. Such cells weighed over twenty pounds, and when properly prepared had an electromotive 